\title{
ORNITHOLOGICAL INVESTIGATIONS IN VIEQUES ISLAND, PUERTO RICO, DURING DECEMBER, 1935
}

\author{
By Stuart T. Danforth, \\ College of Agriculture and Mechanic Arts, University of Puerto Rico, \\ Mayagüez, P. R.
}

Accompanied by Mr. Virgilio Biaggi, Jr., as assistant, the author spent the latter part of December, 1935, in Vieques conducting ornithological investigations. We arrived in the late afternoon of December 23, 1935, and left early in the morning of January 1, 1936. During our stay we visited many localities in the island from Punta Salina on the east to Punta Arena on the west, using an old Ford for transportation which managed to get us into all corners of the island, many times over brush-grown trails where cars had never before seen. By this means we were enabled to cover a much greater portion of the island in the time available than would have been possible by the ordinary means of horseback transportation.

Vieques is an island eighteen miles long and less than four miles in width, situated east of Puerto Rico, the nearest points of the two islands being only six miles apart. Politically the island is considered as a municipality of Puerto Rico. The surface of the island consists for the most part of low hills, which are mostly planted with sugar can on the western half of the island, and covered with a xerophytic or semi-xerophytic growth of woods and brushy vegetation on the eastern half. Birds were much more abundant in the latter region, so we spent most of our time there. A number of salt and brackish lagoons occur in various parts of the island. The largest one is a very extensive mangrove-fringed pond at Playa Grande on the south coast. In the vicinity of Punta Arena there are extensive lagoons and mangrove swamps, and smaller ones exist in many other parts of the island.

During our visit 71 specimens representing 31 species were collected, and notes were made on 23 additional species. Ten species, indicated by an asterisk (*) in the systematic account which follows, had not previously been recorded from the island. The weights of all specimens obtained were recorded, and their stomachs were examined in an effort to determine something of their food habits and economic importance. 
A brief description of the principal collecting localities is appended.

Campaña: A locality on the north coast about five miles east ef Isabel II, approximately where cultivation ceases and the wild, brushgrown eastern part of the island begins.

Cayo Verdiales: A broad peninsula on the south coast, marked on some maps as Puerto Ferro, but the tiny settlement known as Puerto Ferro is somewhat to the east of its base. This peninsula, (for some inexplicable reason known locally as a "cayo"), is overgrowu with xerophytic brush, and there is a lighthouse near its tip. Near its base are mangrove swamps and grassy fields.

Ensenada Honda: The region near a bay in the southeast part of the island is known by this name. It is mainly a region of dense, brushy hills, but in places these have been partially cleared for raising cattle, and near the coast there are some mangrove swamps, lowland woods, and tangled lowland vegetation.

Isabel II: The principal town and port of the island, situated on the norih coast aproximately midway between the eastern and western extremities of the island.

Mosquito: A point on the north coast approximately midway between Isabel II and Punta Arena. It is in the center of the cultivated region.

Playa Grande: Point on the coast in the southwest part of the island where the only remaining sugar factory on the island is located. Near it is an extensive brackish water lagoon, fringed in large part by mangroves.

Puerto Diablo: Point on the north coast of the island in the wild eastern quarter of the island. Most of the hills in the vicinity are covered with xerophytic woods and brush; near the coast are some small mangrove-bordered lagoons.

Puerto Negro: Point on the north coast about half way between Isabel II and the eastern end of the island. The country is very similar to that around Puerto Diablo.

Punta Arena: The western tip of the island, closest to Puerto Rico. In its vicinity are extensive lagoons and mangrove swamps. A short distance southeast of it rises Mt. Pirata (981 feet), the highest point of land on the island.

Punta Salina: A low-lying xerophytic region near the eastern tip of the island. Two brackish lagoons, dry at the time of our visit, occur there. The hills just west of this region are very wild and covered with dry brushy vegetation. 


\section{Annotated List}

* 1. Podilymbus podiceps antillanum Bangs Antillean Grebe

Two observed on the lagoon at Playa Grande on December 25, 1935, constitute the first definite record of this species for the island.

2. Pelecanus occidentalis occidentalis Linnaeus West Indian Brown Pelican

Fairly common along the coasts. Observed at Playa Grande, Isabel II, Campaña, Puerto Negro, Punta Salina, and Cayo Verdiales.

\section{* Ardea herodias herodias Limnaeus Great Blue Heron}

One was observed at Punta Arena December 24, and another at Playa Grande December 25. Not previously recorded from the island.

\section{Leucophoyx thula thula (Molina) Snowy Egret}

Thirty were recorded at the lagoon at Playa Grande on Decernber 25 .

\section{Hydranassa tricolor ruficollis (Gosse)}

Louisiana Heron

Ten were observed at the lagoon at Playa Grande on December 25 , constituting the first record for the island.

6. Florida caerulea caerulescens (Latham)

Southern Little Blue Feron

Common in mangrove swamps, lagoons, and along the coast. The stomach of a male collected December 25 at Playa Grande contained fragments of small crabs. The specimen weighed 408.2 grams.

\section{Butorides virescens maculatus (Boddaert) \\ West Indian Green Heron}

Rather scarce; a few were observecl at Punta Arena, Playa Grande, Puerto Negro and Cayo Verdiales. 
THE JOURNAL OF AGRICULTURE OF THE UNIVERSITY OF P. $R$.

* 8. Nycticorax nycticorax hoactli (Gmelin)

Black-crowned Night Heron

Fifty adults were observed at the lagoon at Playa Grande on December 25. This is the first record for the species in any of the smaller islands near Puerto Rico.

\section{Nyctanassa violacea violacea (Linnaeus) \\ Yellow-crowned Night Heron}

One was observed at Punta Arena on December 24, and two at Playa Grande the following day.

\section{* 10. Querquedula discors (Linnaeus)}

Blue-winged Teal

Eleven were flushed in open spots in mangrove swamps near Punta Arena on December 24. On December 28 one was observed at a small pool in a creek near Isabel II. Not previously recorded from the island.

\section{Nyroca affinis (Eyton) \\ Lesser Scaup Duck}

About 300 were present on the large lagoon at Playa Grande on December 25.

12. Buteo borealis jamaicensis (Gmelin)

West Indian Red-tailed Hawk

One adult was observed at Punta Salina on December 28, two at Ensenada Honda the next day, and one at Campaña on December 31.

\section{Pandion haliaëtus carolinensis (Gmelin) Osprey}

Two were seen at Punta Arena on December 24.

\section{Falco sparverius loquaculus (Riley) Puerto Rican Sparrow Hawk}

Rather scarce, observed only at Isabel II, Puerto Negro and Punta Salina. A male collected at Puerto Negro on December 28 weighed 94.8 grams. It had eaten an Anolis lizard, 2 grasshoppers (Schistocerca colombina), and a spider. 


\section{Rallus longirostris limnetis Oberholser}

Puerto Rican Clapper Rail

Recorded at Punta Arena, Playa Grande, and Cayo Verdiales.

\section{*16. Porzana carolina (Linnaeus) \\ Sora Rail}

Two were observed and a male weighing 101.9 grams was colleced at Playa Grande on December 25, constituting the first record for the island.

\section{Gallinula chloropus portoricensis Danforth Antillean Gallinule}

Common at Punta Arena, Playa Grande and Puerto Negro.

\section{* 18. Fulica caribaea Ridgway Caribbean Coot}

Two observed at Playa Grande on December 21 form the first record for the island.

\section{* 19. Charadrius vociferus vociferus Linneaus Killdeer}

The migratory variety of the Killdeer has not previously been recorded from Vieques. On December 28 a female was collected from a flock of three at Puerto Negro. It weighed 80.3 grams, and its stomach contained 12 Stratiomyid larvae, fragments of Coleoptera, and some gravel.

\section{Charadrius vociferus ternominatus Bangs and Kennard Antillean Killdeer}

A flock of six of the resident variety of the Killdeer was observed at Punta Salina (December 28), and a female weighnig 74.3 grams was collected. Its stomach contained exclusively insect fragments, 95 per cent of them being Coleoptera, largely weevils.

\section{Actitis macularia (Linnaeus) \\ Spotted Sandpiper}

Three were observed at Punta Arena on December 24, two at Playa Grande the 25th, and one at Puerto Negro the 26th. 
644 THE JOURNAL OF AGRICULTURE OF THE UNIVERSITY OF P. R.

\section{Totanus flavipes (Gmelin)}

Lesser Yellowlegs

Common; observed at Punta Arena, Playa Grande, Puerto Negro. and Cayo Verdiales. A female collected at Puerto Negro December 26 weighed 77.7 grams, and had eaten a large number of insects and their larvae.

23. Zenaida aurita zenaida (Temminck) Zenaida Dove

A few were observed at Puerto Diablo and Cayo Verdiales, and larger numbers at Punta Salina, where on December 28 a femaleweighing 116.7 grams was collected. Its crop contained seeds and small stones.

\section{Columbigallina passerina portoricensis (Lowe) Puerto Rican Ground Dove}

Comon and generally distributed. A female collected at Punta Arena December 24 weighed 31.1 grams, and a male from Puerto Negro December 27 weighed 32.8 grams. Both had the bill red at the base and dusky at the tip, and both had eaten large numbers of small seeds.

\section{Coccyzus minor teres Peters \\ Mangrove Cuckoo}

Males collected at Puerto Diablo December 27 and at Campaña December 31 weighed 58.3 and 61.4 grams respectively. The first had eaten 2 katydids (Microcentrum) and $21 \mathrm{eggs}$ of the same. The stomach of the second contained a large walking stick and 16 katydid eggs.

\section{Crotophaga ani Linnaeus}

\section{Ani}

Common; observed at many localities. Two females were collected at Campaña on December 26. One of these contained an egg wiht a fully formed shell, blue with a white chalky covering. They weighed 88.5 and 115.6 grams, and their stomachs contained 95 per cent of insects, consisting of 2 grasshoppers (Schistocerca colombina), Coleoptera, and other insects. A small crab in one stomach formed the other 5 per cent of the food. 


\section{Gymnasio nudipes newtoni (Lawrence)}

Newton's Owl

Inhabitants of the eastern part of the island gave me very convincing evidence that owls occur in the wooded hills slightly west of Punta Salina, but it proved impossble to capture any during our stay to determine if true nudipes or newtoni is the form found there. It is here listed as newtoni tentatively on the basis of probability.

\section{Antrostomus carolinensis (Gmelin) \\ Chuck-will's widow}

A pair was observed and the male collceted on a dense brush covered hill at Punta Salina on December 28. The specimen weighed 133.5 grams, and its stomach contained comminuted insects, mostly Coleoptera, including Phyllophaga and several species of weevils.

\section{Orthorhynchus exilis exilis (Gmelin) \\ Crested Hummingbird}

Common; observed at many localities. A pair was collected at Punta Arena on December 24. The male weighed 2.5 grams and the female 2.4 grams.

\section{Sericotes holosericeus holosericeus (Limnaeus) \\ Blue-breasted Hummingbird}

Common at Punta Arena, where a male weighing 5.3 grams was collected on December 24. One was observed at Punta Salina on December 28.

\section{Megaceryle alcyon alcyon (Linnaeus) Belted Kingfisher}

Seven individuals were observed during our stay, at Punta Arena, Playa Grande and Puerto Negro.

\section{Melanerpes portoricensis (Daudin) \\ Puerto Rican Woodpecker}

Fairly common on the hills covered with brushy woods in the eastern half of the island. Two males collected weighed 70.7 and 72.4 grams, and an unsexed bird weighed 64.7 grams. Of the stomach contents of these three birds Cerambycid larvae formed 35.0 per cent; a Buprestid larva 3.3 per cent, insects, largely Coleoptera, including 
a weevil of the genus Anchomus, 33.3 per cent; a scorpion 5 per cent, and large seeds of some drupe 23.4 per cent. A large parasitic nematode was found loose in the body cavity of one of the specimens.

\section{Tyrannus dominicensis dominicensis (Gmelin) Gray Kingbird}

Very common and generally distributed. As many as eight were noted perched in one tree. The stomach contents of three specimens consisted exclusively of Hymenoptera. One bird had eaten a spider wasp, Pepsis rubra; another 8 bees, Monobiella atrata and the third 2 wasps, Eumenes ornatus. Two males weighed 45.5 and 42.3 grams, and a female 44.9 grams.

\section{Tolmarchus taylori (Sclater) \\ Puerto Rican Petchary}

Common in the brush-covered hills of the eastern third of the island, particulraly in the vicinity of Puerto Diablo. Other localities at which it was fairly common were Campaña, Ensenada Honda and Punta Salina. Three specimens were collected, their stomachs containing 63.3 per cent of vegetable matter (drupes), and 36.7 per cent of animal matter (a weevil and a katydid, Microcentrum sp.). Two males weighed 52.9 and 52.2 grams, and a female 53.7 grams.

\section{Myiarchus antillarum (Bryant) \\ Puerto Rican Flycatcher}

Not definitely identified on our visit, though a bird seen at Cayo Verdiales on December 30 may have been this species. A local hunter who claimed to know the species well stated that it was common before the hurricane of 1928 , but that it has practically disappeared from Vieques since then.

\section{Elaenia martinica riisii Sclater Riise's Elaenia}

Very common in brushy country in all parts of the island, and found even in the drier parts of the mangrove swamps, as at Punta Arena. Seven specimens were collected with some difficulty, as the birds have a habit of remaining concealed in the foliage when singing. Their stomachs contained 97.7 per cent of drupes and seeds, and 2.3 per cent of small weevils. All the specimens were males, and they weighed 18.1, 18.2, 18.6, 18.7, 19.0, 19.6 and 19.6 grams (average 18.83 grams). 
* 37. Hirundo erythrogaster Boddaert

Barn Swallow

Six were observed at Puerto Diablo on December 27, one at Cayo Verdiales on December 30 and three at Campaña on December 31. Not previously recorded from the island.

\section{Mimus polyglottos orpheus (Linnaeus) Jamaican Mockingbird}

Common in the eastern part of the island, not observed in the western end. A male collected weighned 52.7 grams, and two females 50.7 and 55.1 grams. Their stomachs contained vegetable matter 88.7 per cent (wild berries and drupes, and a wild solanaceous fruit), and animal matter 11.3 per cent (a large Geometrid larva in one stomach).

\section{Margarops fuscatus fuscatus (Vieillot) \\ Pearly-eyed Thrasher}

Fairly common on brush-covered hills in the eastern part of the island. A specimen was collected at Punta Salina December 28, and two at Ensenada Honda the next day. All were males, and weighed 91.2, 99.4, and 104.6 grams respectively. The first had eaten two red fruits known as muñeco (apparently Cordia borinquensis), the latter two stomachs contained fruits each of which had 2 coffeelike seeds.

40. Coereba portoricensis sancti-thomae (Sundevall)

Virgin Islands Honey Creeper

Common and generally distributed. Three males collected weighed 9.3, 9.7 and 10.5 grams, and a female 9.4 grams. Two stomachs were empty. The other two had had fruit pulp 35 per cent, and small insects and spiders 65 per cent.

\section{Mniotilta varia (Linnaeus)}

Black and White Warbler

One was observed at Punta Arena on December 24.

\section{Compsothlypis americana pusilla (Wilson) \\ Northern Parula Warbler}

Very common, as many as fifty being observed in the course of a morning's collecting. Nine were collected for a study of plumage variation. Five males weighed $7.2,7.3,7.3,7.3$, and 7.5 grams 
(average, 7.32 grams), and three females 6.5, 7.1, and 7.1 grams (average 6.9 grams). One unsexed bird weighed 8.0 grams. The nine stomachs contained exclusively insects and their larvae and eggs, and spiders. Lepidoptera were represented by caterpillars and the eggs of moths. Coleoptera of many kinds were found, including weevils, fleabeetles, and a small ladybird beetle, Scymnus floralis roseicollis. Some Locustid eggs and various species of Diptera were also encountered.

\section{Dendroica petechia cruciana Sundevall Puerto Rican Golden Warbler}

Common, both in mangrove swamps and in dry brushy regions. A female weighing 10.9 grams was collected at Punta Arena 0. December 24, and a male weighing 10.7 grams at Puerto Negro on December 27. The stomachs of both contained comminuted insects.

\section{Dendroica coronata coronata (Linnaeus) Myrtle Warbler}

Two were observed in a mangrove swamp at Punta Arena December 24, and one of them, a male, was collected. It weighed 11.4 grams, and its stomach was filled with comminuted insects.

\section{Dendroica adelaidae Baird Adelaide's Warbler}

Common on brush covered hills in the vicinities of Puerto Diablo, Punta Salina and Ensenada Honda, and a few were observed at Cayo Verdiales and Campaña. They were noticeably very much shyer than on Puerto Rico, remaining hidden in the densest brush. It was as a result of much strenuous effort that three specimens were secured. Two males weighed 7.1 and 7.3 grams; the third was too damaged to save. The three stomachs contained insects and their eggs, caterpillars and spiders. Fleabeetles and Fulgoridae of the subfamily Issinae figured largely among the insects. Eight large moth eggs were found in one stomach.

\section{Dendroica discolor discolor (Vieillot) \\ Prairie Warbler}

Common; observed in many localities. Males collected December 26 at Puerto Negro and the next day at Puerto Diablo each weighed 7.4 grams. Their stomachs contained exclusively insects 
with the exception of one small spider. Diptera and Coleoptera predominated among the insects; a fleabeetle of the genus Noclonotus was detected in one of the stomachs.

\section{Seiurus aurocapillus (Linnaeus) \\ Oven-bird}

Males collected at Ensenada Honda December, 29, and Campaña December 31 weighed 19.6 and 17.2 grams respectively. Their stomachs contained 50 per cent of seeds and 50 per cent of beetles (mainly weevils and Carabidae), in adclition to sand and gravel.

48. Seiurts noveboracensis noveboracensis (Gmelin) Water-thrush

Observed frequently during the period of our visit. Females were collected at Punta Arena on December 24 and at Cayo Verdiales on December 30, weighing 14.3 and 15.6 grams. The first had eaten 2 dragonfly naiads, the second miscellaneous insects, including Coleoptera.

\section{* 49. Oporormis philadelphia (Wilson) Mourning Warbler}

One was observed in a dense lowland thicket at Ensenada Honda on December 29, but it proved impossible to collect it.

\section{Setophaga ruticilla (Linnaens) Redstart}

A brliliant male was collected December 29 at Ensenada Honda. It weighed 7.6 grams, and its stomach contained exclusively insects and their eggs. Homoptera formed 70 per cent, including 2 leafhoppers, Colpoptera maculifrons. 5 moth eggs formed 10 per cent.

\section{Holoquiscalus niger brachypterus (Cassin) Puerto Rican Grackle}

Decidedly scarce and local at the time of our visit, though it was stated to be common at the time of cane harvesting. One was seen at Mosquito on December 24, and five at Cayo Vercliales on December 30, of which three were collected. Of these an immature female weighed 53.5 grams, an immature male 54.9 grams, and an adult male 83.8 grams. Their stomachs contained 66 per cent of vegetable matter (fruits and laves) and 34 per cent of insects, mainly Coleoptera and lepidopterous pupae. 


\section{Tiaris olivacea bryanti (Ridway) \\ Bryant's Grassquit}

Comon in the vicinities of Campaña, Ensenada Honda and Cayo Verdiales. A male was collected at Campaña on December 26, and three males at Cayo Verdiales on December 30. They weighed 7.8, 8.5, 7.7 and 7.6 grams respectively. Their stomachs contained small seeds and sand.

\section{Tiaris bicolor omissa Jardine}

Carib Grassquit

Abundant and generally distributed. A male weighed 9.7 grams and a female 10.2 grams. Their stomachs contained small seeds and sand.

\section{* 54. Ammodramus savannarum borinquensis Peters} Puerto Rican Grasshopper Sparrow

Two were noted in a grassy field dotted with brushy trees at Cayo Verdiales on December 30, but as it proved imposible to collect any to determine with certainty their subspecific identity, they are here listed under the name of borinquensis on the grounds of probability, no Grasshopper Sparrows having been previously reported from Vieques. 